\title{
BPR AND ERP: THE CHICKEN OR THE EGG
}

A discussion regarding the options management face when thinking about changing processes or IT infrastructures of organisations.

By

René Pellissier $^{1}$ and Albert Kleynhans ${ }^{2}$

\begin{abstract}
Well-known management guru, Tom Davenport, views as a key success factor to a holistic approach to ERP-related change, the need for a simultaneous and integrated approach to strategy, organisation, process and systems change. In this paper, the key issue under discussion is the timing of business process reengineering (BPR), and the implementation of an integrated package solution (ERP) solution, i.e. should these happen simultaneously or should the one be before the other. Consequently, these three alternatives are considered together with respective associated benefits and risks. None provides a clear-cut indication of a "best" approach towards BPR and/or $E R P$. Given the similar approaches to ERP and BPR, a hybrid approach is suggested with projects containing separate but integrated reengineering and system implementation components.
\end{abstract}

\section{OPSOMMING}

Die bekende bestuurskundige, Tom Davenport, beskou the behoefte aan 'n gelyktydige en geintegreerde banadering tot strategie, organisasie, proses-en stelselsverandering, as kernsuksesfaktor tot 'n stelselsbenadering tot ondernemingshulpbronbeplanning (ERP)-verwante verandering. In hierdie artikel, is die fokus op die tydsberekening vir besigheidsherontwerp (BPR), asook wanneer 'n maatskappy oorweging moet skenk aan die implementering van 'n geïntegreerde (ERP) oplossing, d.w.s. behoort implementering gesamentlik plaas te vind, of andersins, watter behoort eerste plaas te vind?. Gevolglik word drie alternatiewe ondersoek., asook die geassosieerde risikos en voordele van elk. Geeneen bied 'n duidelike aanduiding van 'n "beste" benadering tot BPR of ERP nie. Gegewe die soortgelyke benaderings tot ERP en BPR, word 'n hibriede benadering voorgestel met projekte wat afsonderlike, maar geintegreerede herontwerp en komponente vir stelsels-implementering bevat.

\footnotetext{
' Rene Pellissier is associate professor at UNISA's Graduate School of Business Leadership, Box 392, Pretoria. 0003.

${ }_{2}^{2}$ Albert Kleynhans is consultant at KPMG, California
} 
Davenport's [1] advice for an integrated approach might be a little late for many organisations already well underway with ERP implementations. The tough choice many organisations faced during the past years (and some of the late adopters still face this) concerns whether to reengineer processes before implementing ERP solutions; at the same time of implementing ERP; or after the implementation. In some instances they even question whether they really need any form of process review.

In many instances, the $\mathrm{Y} 2 \mathrm{~K}$ threat answered this - in the end there was no time left for both reengineering and solving information architecture problems. The trusted wisdom of not automating old, inefficient processes, or "paving the cow paths", as Hammer [7], father of Business Process Reengineering puts it, is being ignored with lack of resources (especially time) as the culprit.

The days of reengineering being the solution may be over, but it is generally accepted that the need to identify, improve and manage business processes has not disappeared with the decline in popularity of reengineering. More than ever, do organisations realize the true cost and restrictions outdated processes place on them. ERP has been seen as the silver bullet to resolve $\mathrm{Y} 2 \mathrm{~K}$ issues and clean up processes at the same time. ERP software is designed to model and automate many of the basic business processes of an organisation, with the goal of integrating information across the company and eliminating complex, expensive links between legacy systems - the latter seemingly the strongest driver towards ERP. The price organisations have to pay for this automation is generally high. According to Davenport [2] the real challenge organisations face after successful ERP implementations is "to use the resulting process-oriented real-time, global information to change how the company manages and does business."

The key questions to be answered when organisations consider ERP and reengineering are:

- To what extent the reengineering is needed

- Which processes should be reengineered

- When this should be done (before, during or after the ERP project)

- What the benefits and risks to be considered are.

This leads to the key focal point of this paper, i.e. where does reengineering (or process redesign or whatever a company wants to call its cleanup of existing ways of doing business) fit in with ERP.

\section{BPR AND ERP: THE ALTERNATIVES}

Following from the above, three alternatives come to mind:

\subsection{Reengineer first, then automate}

In the perfect world, one would like to complete rigorous reengineering, using a cleansheet approach before looking at any system solution. ERP would then be waiting; ready to automate and fulfill the company's every demand streaming from the new 
processes. This is not quite true. If one takes a "blue sky" approach to reengineering, the results often do not translate into implementable solutions. SAP R/3, the leading ERP package, hardly offers a clean sheet of paper for process reengineering. The package, or any of the major ERP packages for that matter, consists of a complex array of structured processes, which will dictate change and subordinate ambitious reengineering goals to getting the system up and running. Thus, it brings its own reengineering (second generation reengineering), but with a different set of objectives

Davenport, who assisted in the creation of reengineering together with Michael Hammer and James Champy, equate the "Let's reengineer from a clean sheet of paper and then see what ERP can do for us" to an approach like "We'd like to rewrite one of the SAP modules" (Davenport, [2]). And, according to Bancroft [3]: "You don't want to get too far down the reengineering path without keeping $R / 3$ in mind".

\subsection{Reengineering and automate all at once}

In theory, this may sound like a good approach. The reality of ERP packages like SAP, Oracle and Peoplesoft, are that they are extremely difficult to implement. The major reason for this is the way they change people and their roles in the organisation. People are dealing with levels of integration never experienced before. ERP forces every employee who touches it to understand exactly what their business is about, and how it will impact on their customers (internal and external).

In implementing SAP R/3 without prior reengineering, $\mathrm{SAP} R / 3$ could dictate the business process design, which could either be to the benefit or the peril of the company, depending on its specific circumstances.

Many projects start as a combined ERP and reengineering project, and end as either implementing old processes or "generic, out of the box" processes, due to budget and timeline constraints, and the complexity of ERP package implementation.

\subsection{Implement ERP first; reengineer afterwards from a stable base}

This has become a very alluring alternative. Organisations see ERP as the opportunity to stabilise infrastructure problems and cost, eliminating complex interfaces between legacy systems never developed to talk to each other while solving Y2K problems. The added benefit is then perceived to be the opportunity to reengineer later from a stable base.

The biggest problem with this approach, apart from the costliness (both in real and opportunity costs) resulting from automating old processes, is that organisations almost always seem to underestimate the impact ERP would have on their organisations. This culture shock remains for months, if not years after implementation. ERP software imposes major changes to the very nature of what people do. (For example, it will transform order-entry clerks into business people, impacting on the company with every transaction they do.)

Another downside of first implementing ERP, is that the software cannot address operational inefficiencies that arise due to policy or process flaws. The ERP solution 
works according to pre-defined policies and procedures. Operational processes need to be optimised before an ERP implementation. This is the main reason why an ERP implementation project is typically preceded by a reengineering exercise.

For the many organisations implementing ERP without prior reengineering, the approach should be to complete the implementation, stabilise the company and then perform reengineering on selected processes, hopefully with the benefit of hindsight.

The above three alternatives are summarised in Table 1.

Table 1: Summary of options

\begin{tabular}{|c|c|c|}
\hline CLEAN SHEET BPR & $\begin{array}{l}\text { BALANCED } \\
\text { APPROACH } \\
\end{array}$ & $\begin{array}{l}\text { ERP DRIVEN } \\
\text { APPROACH }\end{array}$ \\
\hline Out of the box thinking & Best of both worlds & $\begin{array}{l}\text { "Quick and dirty" } \\
\text { approach }\end{array}$ \\
\hline Clean slate & Use ERP as roadmap & Risk of generic processes \\
\hline $\begin{array}{l}\text { Unattainable goals might } \\
\text { be set }\end{array}$ & $\begin{array}{l}\text { Shorter time to real benefit } \\
\text { possible }\end{array}$ & $\begin{array}{l}\text { Risk of automating } \\
\text { inefficient processes }\end{array}$ \\
\hline $\begin{array}{l}\text { Could be difficult to set } \\
\text { tangible goals }\end{array}$ & $\begin{array}{l}\text { Continuity of project team } \\
\text { and business } \\
\text { representatives }\end{array}$ & ERP dictates processes \\
\hline $\begin{array}{l}\text { Rework to fit IT solution } \\
\text { Time \& resource intensive }\end{array}$ & $\begin{array}{l}\text { Re-work could be limited or } \\
\text { even avoided }\end{array}$ & $\begin{array}{l}\text { Shorter time to systems } \\
\text { benefits }\end{array}$ \\
\hline & $\begin{array}{c}\text { Could have serious impact } \\
\text { on business resources }\end{array}$ & \\
\hline
\end{tabular}

\section{ERP SOLUTIONS: THE GOOD NEWS AND THE BAD NEWS}

Managers utilise scarce resources only if they take an enterprise-wide perspective. This is where ERP comes into play. ERP, utilising packaged software solutions, enable organisations to integrate major areas of their business such as finance, distribution, sales plant maintenance and production planning.

Application packages have largely become a part of the average technology architecture. It is important to understand how these packages are selected and deployed, and what will be needed to integrate the software into existing environments.

The good news about ERP packages are:

- They can be faster and easier to implement than custom developed systems or a mixture of best-of-breed solutions; 
- Best practice business rules and workflow tend to be already implemented in the package application;

- Packages come with regular upgrades and support, enabling organisations to keep up with new trends and statutory requirements e.g. the Euro dollar, and budget for maintenance as a stable cost;

- ERP packages have a positive influence on communication within a company - it forces individuals, departments and functions to communicate;

- As mentioned, it helps individuals realize their role in the larger organisation. Everybody touching the software has a "customer" that will be influenced by it.

It goes without saying that there is a price to pay for the mentioned advantages. These include:

- The temptation to engage in "silver bullet" thinking (thinking the application would provide the complete solution to all organisational problems).

- A loss of in-house control over features and functionality.

- The inability to meet unique business requirements, or use information systems as a competitive advantage.

- Expensive and time consuming to implement and stabilise within the organisation.

Implementing an ERP package is no easy task. Many organisations have tried and failed, and the list is growing. It will require $100 \%$ commitment from the sponsors and the project team, and continuous executive support to improve changes of success.

If ERP is correctly implemented, with clean processes driving the business, the results could be spectacular. Dell Computers, and their DIRECT MODEL (refer Figure 1) is a good example. Dell's success is partly due to the way they use information to speed up execution of every aspect of their business. True virtual integration is the next step beyond the Dell model, and requires reengineering with the complete value chain seen as one. The following diagram reflects the evolution an organisation could face by utilising the best of ERP and reengineering. 


\section{The DOMINANT MODEL}

a value chain with arms length transactions from one layer to the next.
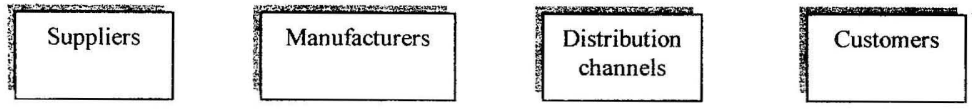

\section{The DIRECT MODEL}

eliminates the time and cost of third-party distribution (made popular by Dell).
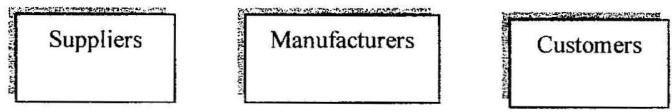

\section{VIRTUAL INTEGRATION}

made possible by ERP solutions with EDI capabilities, blurs the traditional boundaries and roles in the value chain.

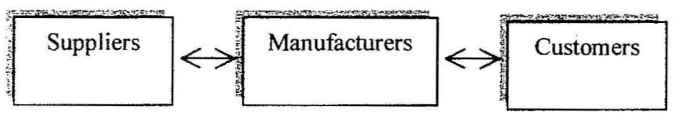

Figure 1: The evolution of a faster business model.

Source: Magretta [5]

\section{EVOLUTION OF A FASTER BUSINESS MODEL}

This evolution above (refer Figure 1is made possible by the successful combination of ERP and business reengineering. It could be possible without the combination, but at substantially higher cost and risk of failure).

Some best practices in performing reengineering and implementing ERP systems will be discussed in the subsequent section.

\section{BPR AND ERP: A BEST PRACTICE COMPARISON}

\subsection{Best Practices for Reengineering}

In their 1995 book, Carr and Johansson [4] identify best practices that organisations adhered too to make their reengineering projects successful. These are listed below with comments added by the authors. 
BEST PRACTICE

Recognize and articulate an extremely compelling need to change

Start with and maintain executive-level support

Understand the organisations readiness to change

Communicate effectively to create buy-in

Create top-notch teams

Use a structured framework

Use consultants effectively

Link goals to corporate strategy

Listen to the voice of the customer

Select the right processes for engineering

Maintain focus - Do not try to engineer too many processes.

Maintain teams as the key

vehicles for change

Quickly come to an As-Is understanding of the processes to be reengineered

\section{COMMENTS}

For most organisations even considering reengineering, there are very obvious and compelling needs to change. Out of control costs, falling profits and margins and many other reasons could drive this.

Strong leadership by the CEO is important, with buy-in from the executive level.

Understanding the need for change is the easy part. The real challenge lies in determining how ready an organisation is for change, and adjusting the approach accordingly.

Effective communication of decisions and motivations for decisions would play an important part in preventing too much negative political activity.

Form collaborative teams to address specific issues.

The correct use of consultants is a major determinant in the final cost and success of the change. An organisation's in-house skills and readiness to break away from the past, should be considered.

This should be true for both in-house and external customers.

Very important. Given the time and cost constraint, careful selection would be needed.

Selecting the processes that really will reduce cost and affect customer service. 
Choose and use the right metrics

Understand the risks and develop contingency plans

Have plans for continuous

improvement

Source: Carr, D and Johansson, H [4]

\subsection{Best Practices for ERP implementation}

In her guideline 1996 handbook, Bancroft et al [3] list the following critical success factors organisations have to adhere too to increase there chances of an successful implementation (refer Table 3). Comments and interpretations are those of the authors.

\section{Table 3: Critical success factors to successful implementation}

\section{CRITICAL SUCCESS FACTORS COMMENTS}

Understand your corporate culture in terms of readiness and capability for change.

Begin business process changes prior to implementation.

Communicate continuously with all levels of users in the business and set reasonable expectations.

Provide superior executive championship for the project.

Ensure the project manager is capable of negotiating equally between the technical, business and change management requirements.

Choose a balanced team, and give clear role definitions.

Select a good project methodology with measurements.

Train users and provide support for job changes.
Similar to the best practice for reengineering. The readiness is there, and is providing the leadership and direction needed. The political culture of the organisation should also be considered.

Similar to the best practice for reengineering on communication.

Similar to reengineering.

Powerful, experienced leadership is critical. An independent consultant might have to be incorporated on the management team to facilitate and add objective edge to the project management.

Measurements should again tie in with the business drivers for completing a successful project.

Change management would be very important. 
Expect problems to arise, commit to change.

Source: Bancroft, Seip and Sprengel [3]

Comparing these critical success factors with the best practices for reengineering discussed before, there are significant similarities. The software solution under discussion (and the same applies for similar solutions) are known to trigger reengineering to enable implementation.

A general guideline is that minor process adjustments could be accomplished while implementing the system, but large scale engineering should be done before implementation. It is advisable that the reengineering team should obtain some level of training on the system structure, and that at least a high-level initial design be completed of a proposed architecture within the business. Also, at least one system specialist should be included in the reengineering project team to help prevent re-work as far as possible. Reengineering after the system implementation is not advisable, as the system has a strong learning curve and some stability is advisable to give users a change to adopt.

The following factors should be kept in mind:

(i) The time needed to implement the integrated system

It is a fairly time consuming process to successfully implement large integrated systems. Furthermore, it takes a substantial amount of resources to implement this. The timeline issue is generally one of the biggest influences on a decision regarding ERP and/or reengineering. The more immediate risk of having key resources focusing on anything but their most immediate responsibilities for an extended period of time is often a big concern to organisations. Add to that the rapidly changing environments many organisations operate in today, and one.

\section{(ii) The political minefield}

Change brings uncertainty. Uncertainty is a breeding ground for unwanted political activity that could further strain limited resources. Project management, change management and communication are key areas often neglected for either or both the reengineering and ERP projects.

\section{(iii) Unanimous executive sponsorship}

Different opinions regarding the value of ERP and reengineering are to be expected on every level of the organisation. Top management is no exception. To enhance chances of successful change of the magnitude ERP or reengineering dictates, the unanimous support from the executive level needs to be gained, made visible and communicated to the entire business. 


\section{CONCLUDING REMARKS}

Reengineering is never without its risks. The same holds for implementing large, integrated systems into large, complex organisations. The opportunity to see both work in tandem could deliver spectacular results - be this success or failure [Pellissier, 6].

Looking at the above alternatives, none provides "the solution". The bad news is that there is no "perfect solution". The goods news is that, by looking at the best (and worst) these may provide, some guidelines surface that could save suffering and wasted effort.

What can organisations do? Some organisations have done it right - Autodesk and Compaq are two such examples. They selected key processes that needed improvement, redesigned them with the SAP solution in mind, and configured SAP to support the new process designs.

The following guidelines could be of help:

- In the alignment of IT with the business, keep a holistic approach.

- Successful ERP projects should be treated as business projects, rather than IT projects.

- An important underlying reason for organisations implementing a system like SAP, is that management uses the package to bring discipline into the organisation. SAP is used to drive the reengineering focus. The software acts as a template or road map for reengineering.

The following steps are suggested in determining a balanced approach:

1. Make key strategic business decisions regarding processes before starting any reengineering or ERP implementation; agree on the core business and processes supporting them.

2. Decide, at least in principle, on what role IT should play in a final solution (e.g. best of breed, in-house developed or packaged solution).

3. Get familiar with high level opportunities and constraints (SWOT analysis if necessary) that the preferred IT solution(s) would provide the company.

4. Perform the applicable process review, redesign or total reengineering, whatever might be applicable, while keeping the opportunities and constraints of the previous point in mind.

5. Implement the IT solution best supporting your business.

Given the above, a hybrid approach is suggested. Approve one project, containing a reengineering component and an ERP system implementation component, but not execute simultaneously. Given the similar phases and steps needed for both the reengineering and system implementations, a streamlined project under one project manager with the above phases are proposed. Timelines will vary given the unique circumstances and resources available for organisations, but on average, a timeline for a mid-size Fortune 1000 company could be as follows (refer Table 4): 


\begin{tabular}{|lcl|}
\hline PHASE & DURATION & COMPONENTS \\
\hline $\begin{array}{l}\text { Detailed Analysis of As-Is and } \\
\text { scoping }\end{array}$ & 2 months & $\begin{array}{l}\text { Reengineering and System } \\
\text { implementation }\end{array}$ \\
$\begin{array}{l}\text { Reengineering phase and initial } \\
\text { high level design }\end{array}$ & 4 months & Reengineering with System inputs \\
$\begin{array}{l}\text { Detailed Design } \\
\text { Construction phase }\end{array}$ & 3 months & System implementation \\
Implementation and Cut-over & 2 months & System implementation \\
\hline
\end{tabular}

In the end, a balanced and integrated approach is needed - one that will balance the risk of "narrow" or "ERP channeled" reengineering with the risk of rework when trying to implement rigorous "white-paper" reengineered processes using ERP systems.

\section{REFERENCES}

[1] Davenport, T.H. The Fad that forgot people. Fast Company. November 1995

[2] Davenport, T.H. Serving up ERP value. CIO Magazine. February 1, 1998

[3] Bancroft, N.H, Seip, $\mathrm{H}$ and Sprengel, A. 1998. Implementing SAP R/3. Greenwitch: Manning, Second edition.

[4] Carr, D and Johansson H. 1995. Best practices in re-engineering. New York: McGraw-Hill Inc,.

[5] Magretta, J. The power of virtual integration: An interview with Dell Computer's Michael Dell. Harvard Business Review. March-April 1998.

[6] Pellissier, R. 1999. The Impact of information technology on business organisations of the future. $\mathrm{PhD}$ thesis, Department of Industrial and Systems Engineering, University of Pretoria.

[7] Hammer, M. 1990. Reengineering work: Don't automate, obliterate. Harvard Business Review. July-August, p 104-112. 